\title{
Correction to: First records of the genus Sphenopus from temperate waters and lower mesophotic depths
}

\author{
Hiroki Kise $^{1}$ (D) $\cdot$ Takuo Higashiji $^{2} \cdot$ Masanori Nonaka $^{3} \cdot$ Daisuke Uyeno $^{4} \cdot$ James Davis Reimer ${ }^{1,5}$
}

Published online: 8 September 2020

(C) Senckenberg Gesellschaft für Naturforschung 2020

\section{Correction to: Marine Biodiversity (2020) 50: 12 https://doi.org/10.1007/s12526-020-01039-x}

This article reports for the first time on an azooxanthellate brachycnemic zoantharian, Sphenopus marsupialis (Gmelin, 1791) from lower mesophotic depths (114 m depth). We have mentioned that Sphenopus species have so far only been reported only from shallow waters $(<35 \mathrm{~m})$ in the paper. However, Dr. Mark J. Grygier has pointed out to the authors that $S$. marsupialis has previously been reported from upper to mid-mesophotic depths; 50-60 $\mathrm{m}$ in Indian waters (Nagabhushanam and Jothinayagam 1982) and from 40 to $86 \mathrm{~m}$ in Australian waters (Grygier 1991). These previous studies add even further support to our main conclusion that Sphenopus species may be much more widely and commonly distributed across the Indo-Pacific Ocean including at deeper depths. The authors regret that they overlooked the existence of these two previous reports.

\section{References}

Grygier MJ (1991) Additions to the Ascothoracidan fauna of Australia and south-east Asia (Crustacea: Maxillopoda): Synagogidae (part), Lauridae and Petrarcidae. Rec Aust Mus 43:1-46. https://doi.org/10. 3853/j.0067-1975.43.1991.39

Nagabhushanam AK, Jothinayagam JT (1982) Observations on the zoanthid, Sphenopus marsupialis (Gmelin) (Anthozoa: Zoanthidea: Sphenopidae), along the southeast coast of India, with notes on its behaviour in aquaria. Rec Zool Surv India 80(1-2):1726.

Publisher's note Springer Nature remains neutral with regard to jurisdictional claims in published maps and institutional affiliations.

The online version of the original article can be found at https:/doi.org/ 10.1007/s12526-020-01039-x

Hiroki Kise

hkm11sea@yahoo.co.jp

1 Graduate School of Engineering and Science, University of the Ryukyus, 1 Senbaru, Nishihara, Okinawa 903-0213, Japan

2 Okinawa Churaumi Aquarium, Okinawa Churashima Foundation, Motobu, Okinawa, Japan

3 Okinawa Churashima Research Center, Okinawa Churashima Foundation, Motobu, Okinawa, Japan

4 Graduate School of Science and Engineering, Kagoshima University, 1-21-35 Korimoto, Kagoshima 890-0065, Japan

5 Tropical Biosphere Research Center, University of the Ryukyus, 1 Senbaru, Nishihara, Okinawa 903-0213, Japan 